\title{
Islam, Democracy, and Freedom in North Africa
}

\author{
London School of Economics, London, U.K. \\ Shaban 26, 1412/February 29, 1992
}

The Islamic Society of the London School of Economics (London University) recently organized a one-day conference on "Islam, Democracy and Freedom in North Africa." In attendance were scholars from several universities as well as religious leaders and former statesmen. The audience was composed mainly of university students.

The first session featured S. Salaam of the Sorbonne (Paris), who discussed the recent situation in Algeria after touching on late nineteenth- and early twentieth-century social, political, and religious developments. He talked about the ulama's role as a source of mobilization against French colonial rule as well as their attempts to motivate the masses, through their dynamic Islamic teachings, to struggle for the emancipation of Algeria. According to him, the moral and spiritual support of the learned segment of Algerian society enabled the nationalist leaders to unite the people behind a national cause, one which is also conceived of as the religious obligation of jihad. On a more recent note, Salaam noted that the media has attributed the Islamic Salvation Party's (FIS) success in the last elections to Algeria's economic backwardness. While there may be some truth to this argument, the success of Islamic ideology lies in its emphasis on social justice and equality, the strengthening of morality, and the uplifting of Qur'anic teachings. This is in stark contrast to the widespread corruption prevalent among the ruling elite. Salaam argued that the FIS has provided people with an authentic sense of identity which can be used to fill the gaps caused by modernization.

The second paper was presented by Julian C. Hollick, a radio journalist with America's National Public Radio organization. Addressing the topic of Islam and the media, Hollick laid out the Western media's misconceptions and distortions of Islam, which he attributed to either poor journalism or ignorance of (or prejudice towards) Islam. He noted that journalists are not as objective as is commonly believed, for they are products of a given society and share in its stereotypical images and prejudices. These factors can prevent a journalist from penetrating beneath the surface of a foreign culture and society. Hollick proposed that ignorance of different interpretations of events and a superficial study of the phenomenon being investigated results in both poor journalism and a distorted coverage of events. He stated that many Western journalists tend to cover the "pathologic aspects of development" in the Muslim world (i.e., militant Islam and women's rights) since such stories have a greater chance of being 
published or broadcast, especially when they coincide with the already negative (and sometimes hostile) attitudes of editors and are accompanied with effective visual material.

Timothy Niblock (University of Exeter, UK), who presented a paper on "The Role of Europe and Democracy in the Middle East and North Africa," tackled the implications of European intervention in those two areas. He opined that Europe has failed to see the importance of democracy and human rights, as Westerners in general adhere to the traditional colonial preference for economic gain and exploitation. He argued that European governments should not interfere in North Africa's or the Middle East's domestic affairs, since it has been observed that their involvement in the name of high values, modernization, civilization, and so on has created discord and resentment among the area's inhabitants. Niblock concluded his presentation with the assertion that there is only one form of democracy - that is that the people have the right to choose and be represented by their free will irrespective of how others label their choice.

John O. Voll (University of New Hampshire, Durham, NH) spoke on "North African Islamic Movements and Problems of Western Perceptions." He pointed out that various ambiguous concepts employed by researchers and politicians (i.e., democracy, modernism, secularism, fundamentalism, and others) may lead to misunderstandings and misconceptions. To prevent this, these concepts should be defined in a way designed to give a better understanding and a more accurate perception of the problems being examined. After outlining the general features of two contrasting trends of Islamic thought (traditionalism versus modernism), Voll discussed the problems associated with the West's perception of Islamic movements in general and of Algeria's in particular. He suggested that the contemporary leaders and intellectuals of the Islamic movements have to be listened to, and that historical sources must be consulted, in order to analyze current developments correctly. In his concluding remarks, Voll argued that democracy may serve as a revolutionary vehicle if it fails to create a stable and representative regime, and that the overthrow of a dictatorial regime should be seen as a first step towards democratization.

François Burgat (Center of Documentation, Economics, Judicial, and Social Sciences, Egypt) addressed the issue of "The Islamic Movement's Attitude in North Africa towards Democracy." His main theme was the conceptual inability of Western academics to see the importance of various variables that have played effective roles in the development of recent regional events vis-à-vis Islamic consciousness and awareness. Burgat noted that the Western world and media has remained silent over the violation of human rights in North Africa, thereby adopting a double standard.

Mohammed Mzali, former prime minister of Tunisia, explored the colonial experience of North Africa and developments in the process of democratization in a paper entitled "The Current Political Scenario in Tunisia." He also discussed 
the current situation in Tunisia, where a young generation (what he called a "second generation") has raised its voice against corruption among the ruling elite.

Rashid al-Ghanoushi's paper, "Islam and the West," focused on the misunderstanding and misapplication of modernization, a process which was supposed to give priority to freedom of thought and expression in contemporary Tunisia. He argued that the Western model of democracy, based on secularism and modernization, has taken a very different form in Tunisia than it has in the West. Tunisian modernism ended the freedom of expression and silenced those intellectuals whose ideological stand provides the young generation with a sense of Islamic ideology, as opposed to those corrupt ruling elites who exploit modernism to serve their own ends.

John L. Esposito (College of the Holy Cross, Worcester, MA) examined the Western perception of the growing Islamic consciousness in his paper "Democratization, Islamic Movements, and the West." He argued that the escalation of Islamic sentiments, usually referred to by the Western media and scholars as "Islamic fundamentalism," is regarded as a threat to Western interests in Muslim societies. Esposito contended that when religious groups began to vote in elections, they became a threat to both Western interests and to the Westernized elites in Muslim countries who assume that the Islamists are somehow going to hijack democracy.

The conference ended with a paper entitled "Crisis of Democracy in the Maghreb" by Bourhan Ghalioun of the Sorbonne (Paris), who analyzed the process of democratization in the area.

Talip Kucukcan

Research Fellow

Turkiye Diyanet Vakfi

Centre for Islamic Research

Istanbul, Turkey 